\title{
PERANAN SEKTOR PARIWISATA DALAM MENINGKATKAN PENDAPATAN ASLI DAERAH KOTA PALOPO
}

\author{
AHMAR, NURLINDA, MUSTAFA MUHANI
}

\begin{abstract}
ABSTRAK
Penerimaan Pendapan Asli Daerah adalah suatu penerimaan daerah dari berbagai usaha penerimaandaerah untuk mengumpulkan dana,guna keperluan daerah yang bersangkutan.Dalam membiayai kegiatan rutin maupun pembangunan daerah dan yang lain.

Tujuan penelitian ini adalah untuk mengetahu peranan sector pariwisata dalam meningkatkan pendapatan Asli Daerah Kota Palopo serta untuk mengetahui pengaruh antara jumlah pendapatan sector pariwisata terhadap Pendapatan Asli Daerah(PAD) Kota Palopo.Berdasarkan masalah penelitian tersebut metode yang digunakan adalah metode regresi linear sederhana dengan memecahkan permasalahan tersebut.Teknik pengumpulan data yang digunakan dalam penelitian ini adalah dengan penelitian kepustakaan dan penelitian lapangan yang terdiri dari wawancara,observasi,dan dokumentasi.Pada penelitian ini,data yang di analisis bersumber dari pendapatan sector pariwisata terhadap Pendapatan Asli Daerah Kota Palopo.

Hasil penelitian mengenai peranan sector pariwisata dalam meningkatkan Pendapatan Asli Daerak Kota Palopo.Menyatakan bahwa jumlah pendapatan sector pariwisata mengalami peningkatan dan penurunan tiap tahunnya disebabkan oeh factor jumlah wisatawan yang tidak berdasarkan hasil analisis regresi sederhana diperoleh koefisien korelasi antara retribusi pariwisata dengan Pendapatan Asli Daerah Kota Palopo sebesar 70\%.Pengaruh ini menunjukkan bahwa diantara kedua fariabel memiliki hubungan kuat dan positif.
\end{abstract}

Kata kunci: Sektor pariwisata, retribusi daerah, pendapatan asli daerah 


\section{Pendahuluan}

\section{Latar Belakang}

Indonesia merupakan Negara kepulauan terbesar di dunia,dengan 18.120 pulau yang di milikinya dengan garis pantai sepanjang 108.000 km.Negara Indonesia memiliki potnsi alam,keanekaragaman flra dan fauna,peninggalan purbakala,peninggalan sejarah,serta seni dan budaya yang semuanya itu merupakan sumber daya dan modal yang besar artinya bagi usaha pengembangan dan peningkatan kepariwisataan.Modal tersebut garus dimanfaatkan secara optimal melalui penyelenggaraan kepariwisataan yang secara umum yang bertujuan untuk meningkatkan pendapatan nasional dalam rangka meningkatkan kesejahteraan rakyat.

Kegiatan usaha kepariwisataan merupakan salah satu potensi yang sangat besar saat ini di Kota Palopo.pariwisata dikembangkan di suatu daerah dengan berbagai alasan utama adalah untuk menghasilkan manfaat ekonomi dan masuknya devisa bagi daerah dan negara,peningkatan dan pendapatan masyarakat dan pemerintah.pariwisata juga mendorong proses perlindungan terhadap suatu lingkaran fisik maupun social budaya dari masyarakat setempat,karena hal tersebut merupakan asset yang dapat dijual kepada wisatawan dan jika ingin berlanjut maka harus di pertahankan.

Oleh karna itu untuk mengoptimalkan manfaat dan mengurangi berbagai masalah yang di timbulkan dengan adanya pengembangan pariwisata,maka diperlukan perencanaan yang baik dan manajemen yang baik pula.

Pengembangan pariwisata nasional mengacu pada landasan ideal(nilai-nilai agama dan pancasila), landasan konstitusional (UUD 1945 dan UUD No 9 tahun 1990) yang secara operasional dilaksanakan oleh para pelaku utama pengembangan kepariwisataan.

Dengan adanya pengembangan dan peningkatan sarana dan prasarana sector pariwisata khususnya wisata alam,wisata budaya,dan pariwisata pantai,pemerintah kota palopo berusaha untuk meningkatkan pandapatan asli daerahnya terutama yang bersumber dari sector pariwisata.

Sehubungan dengan uraian tersebut di atas,maka penulis tertarik untuk meneliti dan menuangkan dalam bentuk proposal skripsi dengan judul "peranan sector pariwisata dalam meningkatkan Pendapatan Asli Daerah(PAD) Kota Palopo". Masalah Penelitian ini adalah Apakah peranan sector pariwisata berpengaruh terhadap Pendapatan Asli Daerah(PAD) Kota Palopo?. Tujuan Penelitian ini adalah Untuk mengetahui peranan sector pariwisata dalm meningkatkan Pendapatan Asli Daerah(PAD) Kota Palopo. 


\section{Metode Penelitian}

Tempat dan waktu penelitian

Penelitian dengan judul peranan sector pariwisata dalam meningkatkan Pendapatan Asli Daerah (PAD) Kota Palopo dilaksanakan pada Dinas Pariwisata Kota Palopo,dengan waktu penelitian kurang lebih tiga bulan mulai mei sampai denga juli 2012.

Jenis dan Sumber Data

(a) Data Primer; Data yang diperoleh langsung melalui penelitian lapangan atau pengamatan langsung,wawancara langsung,maupun observasi langsung terhadap sumber daya yang dibutuhkan.

(b) Data Sekunder; Data yang diperoleh melalui buku-buku literature atau buku bacaan lainnya seperti tulisan-tulisan ilmiah,teori-teori,diktat-diktat dan pendapat-pendapat yang dipergunakan dalam penulisan proposal ini.

Metode Pengumpulan Data

Metode pengumpulan data dalam penelitian ini yaitu; (a).Penelitian Lapangan(field Research); Penelitian yang dilakukan dengan jalan pengamatan langsung kelapangan atau objek penelitian dengan cara mengadakan wawancara (interview) dengan menggunakan kuesioner, (b) Penelitian Kepustakaan(Library Research); Penelitian yang dilakukan dengan cara mencari reverence yang berupa buku ,majalah,surat kabar,teori-teori lain yang ada hubugannya dengan masalah yang di bahas,serta mengumpulkan data yang telah didokumentasikan oleh,instansi pemerintah/swasta yang relevan dengan penelitian.

Metode Analisis Data

Untuk menguji kebenaran hipotesis yang penulis ajukan maka metode analisis yang digunakan yaitu mempergunakan metode analisis regresi sederhana,menurut Rangkuti (2003:94) analisis sederhana yaitu untuk mengetahui hubungan dan pengaruh variabel-variabel independen terhadap variable dependen.Dengan menggunakan data team series tahun 2006 -2011 yang diolah melalui program SPSS 16.Dengan rumus sebagai berikut:

$\mathrm{Y}=\mathrm{a}+\mathrm{bX}$

Dimana:

$\mathrm{Y}=$ Jumlah PAD Kota Palopo

$\mathrm{X} 1=$ Jumlah tariff danretribusi objek wisata

$\mathrm{a}=$ Konstanta

$\mathrm{b}=$ Parameter regresi yang akan di ukur

\section{Uji Hipotesis}

Untuk menguji hipotesis,akan dilakukan pengujian hipotesis menggunakan uji t (uji parsil) dan uji f (uji simultan) dengan tingkat keyakinan 95\%. 


\section{Definisi Operasional}

Pariwisata adalah perjalanan yang dilakukan untuk sementara waktu,yang selenggarakan dari suatu tempat lain dengan maksud dan bukan untuk berusaha (business) atau mencari nafkah di tempat yang dikunjuginya, tapi semata-mata untuk menikmati perjalanan bertamasya dan rekreasi atau untuk memenuhi keinginan yang beraneka ragam di Kota Palopo.

Sektor pariwisata yang di maksud adalah Dinas Pariwisata Kota Palopo dan mengurus dan mengelola objek-objek wisata di Kota Palopo.

Pendapatan Asli Daerah (PAD) merupakan pendapatan dan belanja Daerah yang berasal dari berbagai sumber yang potensial asli daerah Kota Palopo.

Faktor-faktor yangmempengaruhi peningkatan PAD Kota Palopodari sector pariwisata:

(a) Retribusi Objek Wisata adalah pungutan daerah sebagai pembayaran atas objek wisata perorangan atau kelompok pada objek wisata di Kota Palopo, (b) Tingkat Hunian Hotel; Tingkat Hunian Hotel merupakan suatu keadaan sampai sejauh mana jumlah kamar terjual,jika diperbandingkan dengan seluruh jumlah kamar yang mampuuntuk di jual di Kota Palopo, (c) Pendapatan Perkapita; Pendapatan perkapita merupakan salah satu indicator yang penting untuk mengetahui kondisi ekonomi di suatu wilayah dalam periode tertentu,yang di tunjukkan dengan Pendapatan Domestik Regional Bruto (PDRB) baik atas dasar harga berlaku maupun atas dasar harga konstan di kota palopo.

\section{Pembahasan Dan Hasil Penelitian}

\section{Profil Kota Palopo}

Sejak tahun 2002,Kota Palopo yang dahulunya adalah merupakan ibu kota kabupaten luwu,setelah resmi menjadi kota otonom kini telah membenahi diri menjadi daerah yang siap eksis sebagai pusat perekonomian di tanah luwu sering dengan digaungkannya tujuh dimensi pembangunan kota yang akan mendukung Visi Kota Palopo sebagai salah satu kota pelayanan jasa terbaik di kawasan timur Indonesia.

Pada tingkatan yang luas,laju pertumbuhan ekonomi dan pertumbuhan pembangunan menunjukkan angka yang sangat signifikan,demikian juga dengan income perkapita masyarakat yang menunjukkan grafik yang lebih baik jika di bandingkan ketika masih merupakan bagian dari kabupaten luwu.Kondisi ini menjadi indikasi positif akan hadirnya keadaan masa depan yang lebih baik dan maju di kota palopo.

Denga pertumbuhan yang pesat,kota palopo memiliki potensi luas wilayah dan besar jumlah penduduk.sejalan dengan itudalam rangka efisiensi dan evektifitas menyelenggarakan pemerintahdan pembangunan,maka perlu di adakan pemekaran kecamatan,Kelurahan atau Desa yang berada di dalam kota palopo. 
Adapun yang menjadi latar belakang pemikiran dan pertimbangan ditingkatkan statusnya menjadi kota,karena perkembangan dan kemajuan yang telah menunjukkan cirri-ciri sifat penghidupan perkotaan yang memerlukan pembinaan serta peraturan penyelenggaraan pemerintahan secara khusus.

Keadaan Geografis

Kota palopo secara geografis terletak antara 2,53"15"-3,04"08" Lintang selatan dan 120,03"10"-120,14"34" Bujur Timur,dengan batas-batasnya.

a.Sebelah utara berbatasan dengan kecamatan walenrang Kabupaten Luwu.

b.Sebelah selatan berbatasan dengan Kecamatan Buah Kabupaten Luwu.

c.Sebelah barat berbatasan dengan Kabupaten Tana Toraja.

d.Sebelah timur berbatasan dengan Teluk Bone.

Luas Wilayah

Luas wilayah administrasi Kota Palopo sekitar 247,52 kilometer persegi atau sama dengan $0,35 \%$ dari luas wilayah Provinsi Sulawesi Selatan.Dengan potensi luas seperti itu oleh Pemerintah Kota Palopo telah membagi 9 kecamatan dan 48 kelurahan pada tahun 2005.

Jika diamati menurut kelompok usia untuk dijadikan bahan evaluasi dan perencanaan pembangunan di bidang kependudukan,terlihat bahwa dari 137.595 jiwa penduduk kota palopo sekitar32,73\% pada usia mudah (0-14 tahun) dan 4,42\% pada kelompok usia tua (65 tahun ke atas).Dengan demikian sekitar $62,85 \%$ yang berada pada kelompok usia produktif (15-64 tahun).Dengan kata lain beban tanggungan kota palopo tahun 2010 sebesar59,11\%, artinya penduduk kota palopo yang berusia produktif (15-64 tahun) menanggung beban bagi penduduk yang belum dan atau yang tidak produktif sekitar 59-60\% dari jumlah penduduk secara total.

Peluang dan Tantangan Pengelolaan Objek Wisata di Kota Palopo

Mengacu pada rencana induk pengembangan pariwisata kota palopo,maka arah pengembangan sector pariwisata adalah mengembangkan segenap potensi wisata yang ada seperti wisata bahari,alam,budaya,adat istiadat,sejarah,serta yang lainya dan bekerja sama dengan berbagai instansi yang terkait maka diharapkan adanya informasi yang saling memberikan harapan yang baik kepada masyarakat dalam negeri maupun mancanegara.

Peluang di masa depan dengan pengelolaan objek wisata di kota palopo antara lain:

a.Usaha di bidang pariwisata merupakan usaha yang sangat menjanjikan untuk di kembangkan.

b.Kota palopo memiliki potensi objek wisata dan daya tarik wisata baik wisata alam,seni budaya peninggalan sejara,dan kehidupan masyarakat yang alami serta adat istiadat yang beragam.

c.Memiliki objek wisata unggulan tetapi b belum di kenal secara regional,nasional dan internasional. 
Pembangunan dan pengembangan objek wisata pada dasarnya di bangun atas dasar perluasan wisata,yaitu pengelolaan objek pariwisata yang di pandang memiliki potensi untuk di kembangkan dan menjadi daerah tujuan wisata.

Pengembangan pariwisata diarahkan pada peningkatan pariwisata yang mampu menggalakkan kegiatan ekonomi,kegiatan sector pertanian,industry dan kerajinan rakyat sehingga dapat memperluas kesempatan kerja dan peningkatan pendapatan pendapatan asli daerah kota palopo.

\section{Potensi Objek Wisata Di Kota Palopo}

Secara umum dapat dikatakan bahwa wilayah kota palopo memiliki cukup banyak objek wisata yang sangat potensial untuk menarik para wisatawan untuk berkunjung ke daerah tersebut.Objek wisata alam seperti panorama yang indah,tempat permandian alam,iklim yang sejuk karna berada pada daerah perbukitan,wisata sejarah adalah merupakan kenangan tersendiri dalammenikmatinya.

Saat ini pemerintah kota palopo tidak henti-hentinya melakukan promosi kepariwisataan daerah kota palopo,hal ini di tempuh agar jumlah wisatawan yang berkunjung dapat semakin bertambah sehingga meningkatkan pendapatan asli daerah kota palopo.

Strategi dasar promosi dalam mengembangkan pariwisata kota palopo,dan menggunakan tahapan sabagai berikut:

1. Tahapan perkenalan

a. Memberikan informasi sebanyak mungkin kepada wisatawan.

b. Mengupayakan wistawan mengetahui akan keuntungan memilih objek wisata yang ada di kota palopo.

c.Menstimulasi wisatawan dengan tujuan mempelajari social budaya,keinginanya,kesenangan dan yang lainnya.

2.Tahapan pertumbuhan

a. Promosi yang dilakukan oleh biro-biro perjalanan,hotel-hotel,perusahaan penerbangan dan wisatawan sendiri.

b. Strategipromosi dangan tatap muka di manfaatkan oleh wisatawan yang telah berkunjung ke kota palopo agar nantinya setelah wisatawan tersebut kembali daerah atau negaranya masih rindu akan objek wisata tersebut dan akan mempromosikan secara tidak langsung akan kelebihan objek wisata yang ada di kota palopo kepada teman sekerjanya,profesinya atau orang-orang yang ada di lingkungan daerah asalnya.

3.Tahap Kedewasaan

Di kota palopo personil yang ada di kantor Dinas Pariwisata Kota Palopo dan dia bekali dengan keterampilan (skill) dan pengetahuab yang praktis dan yang memadai sebagai penunjang,sehingga pada gilirannya promosi tatap muka dapat berfungsi dengan baik. 
Potensi-potensi tersebut tersebar pada beberapa lokasi di tempat kecamatan yang ada dalam wilayah kota palopo.potensi-potensi wisata yang di miliki kota palopo yang sangat mendukung untuk di kembangkan selain menjadi daya tarik bagi masyarakat untuk berekreasi,juga dapat menjadi sumber peningkatan pendapatan asli daerah(PAD) Kota palopo.

Adapun potensi wisata yang ada di kota palopo,yaitu:

a .Museum batara guru

b.Pantai labombo

c.jalan lingkar

d.Pulau libukang

e.Pantai songka

Kontribusi Retribusi Pariwisata Terhadap Pendapatan Asli Daerah Kota Palopo

Pendapatan asli daerah dapat di peroleh dari berbagai sector usaha besar seperti,sector pertanian,sector jasa,sector perdagangan,sector industry dll,dan sector pariwisata dapat di kategorikan sebagai sumber pendapatanpada beberapa sector yang secara langsung dapat memberikan pemasukan pada penerimaan PAD.

Berdsarkan perhitungan dapat dibuat persamaan regresi sederhana dengan hasil $a=11,475,482$ dan $b=5,099$. Maka penulis dapat menarik kesimpulan bahwa $\mathrm{a}=11.475 .482$ artinya jika variable retribusipariwisata $\mathrm{O}$ (Konstan), maka besar pendapatan asli daerah (PAD) Kota palopo sebesar Rp.11.475.482 dengan asumsi bahwa variable adalah tetap.

Sedangkan $b=$ Besarnya pengaruh retribusi terhadap pendapatan asli daerah (PAD) Kota palopo adalah sebesar Rp. 57,099 juta /tahun.

Dengan demkian dengan menggunakan uji $\mathrm{F}$ dengan $\mathrm{X} \quad 0,05 \%$ dengan demikian pendapatan sector pariwisata tidak berpengaruh signifikan terhadap pendapatan asli daerah (PAD) Kota Palopo .

\section{Penutup}

Kesimpulan penelitian ini adalah: (a)Bahwa kontribusi retribusi pariwisata terhadap Pendapatan Asli Daerah Kota Palopo pada tahun 2006 yakni 0,33persen dan pada tahun 2007 besarnya kontribusi terhadap Pendapatan Asli Daerah Kota Palopo naik sekitar 0,34 persen kemudian dari ke tahun 2008 kontribusi retribusi terhadap Pendapatan Asli Daerah Kota Palopo hanya 0,27 persen saja,namun pad tahun 2009,kontribusi retribusi pariwisata terhadap Pendapatan Asli Daerah Kota Palopo naik sebesar 0,49 persen,dan tahun 2010,kontribusi retribusi pariwisata terhadap Pendapatan Asli Daerah Kota Palopo hanya sebesar 0,39 persen saja,dan tahun 2011 kontribusi retribusi pariwisata terhadap Pendapatan Asli Daerah Kota Palopo yang diberikan 0,40 persen.Jadi jika di rata-ratakan kontribusi retribusi pariwisata terhadap Pendapatan Asli Daerah Kota Palopo setiap tahunya mencapai rata-rata 0,38 atau $38 \%$. 
(b) Hubungan antara retribusi pariwisata dengan Pendapatan Asli Daerah Kota Palopo yaitu $\mathrm{r}$ adalah 0,773 atau 77,3 persen menunjukkan bahwa antara kedua variable memiliki hubungan yang kuat dan positif, (c) Besarnya pengaruh retribusi pariwisata terhadap Pendapatan Asli Daerah Kota Palopo adalah sebesar Rp.41,053 juta/tahun, (d) Nilai determinasi r2 di peroleh sebesar 0,598 artinya penerimaan retribusi pariwisata berpengaruh terhadap naik turunnya Pendapatan Asli Daerah Kota Palopo sebesar 59,8 persen. Adapun saran penelitian ini adalah:

(a) Diharapkan Dinas Pendapatan Pengelolaan Kekayaan Daerah Kota Palopo memperhatikan sector pariwisata karena dengan retribusi pariwisata itu dapat memberikan kontribusi besar terhadap Pendapatan Asli Daerah Kota Palopo,pada setiap tahunnya, (b) Diharapkan instansi atau pihak yang terkait memberikan dukungan penuh terhadap pengelolaan sector pariwisisata kota palopo.

\section{Daftar Pustaka}

Achmad Fausi dan Iskandar ,2002.Direktoral Jendral Pajak Pariwisata,Pengantar Pariwisata Indonesia,Jakarta.

Badruddin,2001.Cara Membaca APBD,Penerbit Universitas Brawijaya,Malang.

Djojohadikusumo,2001.Indonesia Dalam Pembangunan Dunia Kini Dan Masa Datang,LP3ES Jakarta.

Fandeli,2001.”Analisis Faktor yang Mempengaruhi Penerimaan Daerah dari Sektor Pariwisata”.Disertasi Tidak Dipublikasikan,Fakultas Ekonomi,Universitas Diponerogo.

Gamal Suwantoro,2005."Menggairahkan Bisnis Pariwisata Pada Era Otonomi Daerah".Gema Stikubank.Edisi 33.

Guritno Mangkosubroto,2007.Ekonomi Pembangunan.STIE YKPN,Yogyakarta.

Hari Hartono,2000.Ekonomi Publik.BPFE, Yogyakarta.

M.L Jhingan,2003.Pariwsata Indonesia, Yogyakarta:Kanisius.

Oka A. Yoeti,2004.Ekonomi Pariwisata,Jakarta.Toha Putra.

Rangkuti,2003,Metode Penelitian Bisnis,Alfabeta,Bandung.

Samsubar Saleh,2003.Manajemen Kepariwisataan, PT.Pradnya Paramita,Jakarta 
Ahmor et al- PERANAN SEKTOR PARIUISATA DALAM MENINGKATKAN PENDAPATAN ASLI...

Suparmoko,2001.'Kemampuan Pinjam Daerah Kabupaten dan Kota di Indonesia",Vol.XIV,Semarang:Media Ekonomi Dan Bisnis.

1999.Undang-Undang Republik Indonesia Nomor 22 tentang Pemerinta Daerah.

2000.Undang-Undang No.9 Tentang Kepariwisataan.

2004.Undang-Undang No 5 Tahun Tentang Pengelolaan Objek

Wisata.

2009.Undang-Undang RI No.10 Tentang Pariwisata.

Waluyo,2006.’Perpajakan Indonesia 2,10E”salemba. 